\title{
PREPARATION OF A STABLE HUMAN PLASMA PROTEIN SOLUTION ${ }^{1}$
}

\author{
By DWIGHT J. MULFORD, EDWARD H. MEALEY, ANd LEWIS D. WELTON
}

(From the Department of Biochemistry, The University of Kansas, Lawerence, Kan.)

(Submitted for publication December 6, 1954; accepted January 12, 1955)

Studies on the effect of heat on the virus of serum hepatitis have shown that a mixture of normal serum albumin and proved icterogenic plasma failed to produce serum hepatitis when inoculated into volunteers after it had been heated at $60^{\circ} \mathrm{C}$. for 10 hours (1). Studies by Murray and Diefenbach (2) on the effect of heating infected plasma pools showed that after four hours heating at $60^{\circ} \mathrm{C}$. the infected plasma pools retained their ability to produce hepatitis. A statement was made in their paper that heating for four hours or more at $60^{\circ} \mathrm{C}$. led to an increase in turbidity and formation of a precipitate (2). With these two facts in mind plus the fact that a plasma protein solution heated for 10 hours at $60^{\circ} \mathrm{C}$. might be clinically useful, we decided to investigate the possibility of preparing a plasma protein solution that could stand heating for 10 hours at $60^{\circ} \mathrm{C}$. with little or no change in the proteins.

The present communication concerns the heat stability of the human plasma protein solution remaining after the crude fibrinogen and gamma globulin fractions have been separated from human plasma by ethanol-water mixtures at low temperatures.

\section{METHODS AND RESULTS}

The procedure for the separation of the crude fibrinogen fraction, Fraction I and the crude gamma globulin fraction, Fraction II + III was in part similar to that using ethanol at low temperatures (3). Fractions $I$ and II + III were removed from the starting plasma for three primary reasons. First, the proteins contained in these two fractions have only a minor role in the colloid osmotic pressure of plasma. Second, the proteins fibrinogen and gamma globulin, contained in Fractions I and II + III, respectively, could be salvaged for their specific clinical uses; i.e., afibrinogenemia, hemophilia and other coagulation component defects, agammaglobulinemia

\footnotetext{
1 This investigation was supported in part by a research grant (H1229) from the National Heart Institute, of the National Institutes of Health, Public Health Service, and in part by the University of Kansas, General Research Project 151.
}

and specific infections requiring prophylaxis with antibodies. Third, Fractions I and II + III contain most of the more heat labile components of human plasma. The supernatant fluid following the removal of Fractions I and II + III was dried from the frozen state. The powder obtained was the material used in this investigation.

Plasma used in the preparation of this material was supplied by the American Red Cross through its Regional Blood Centers at Omaha, Nebraska, and Springfield, Missouri. The plasma was pooled at the Blood Center into two-liter bottles and ten liters were shipped to us each week. No attempt was made to keep the plasma cold while en route. Upon arrival at the laboratory each bottle was placed in a freezer kept at $-18^{\circ} \mathrm{C}$. When ready for processing, the plasma was thawed in a bath maintained at $37^{\circ} \mathrm{C}$. and the separation of Fraction I and II + III was started immediately.

\section{Separation of Fraction I}

Fraction I was separated by 8 per cent ethanol, $\mathrm{pH}$ $7.2 \pm 0.2, \Gamma / 2=0.14$, and temperature $0^{\circ} \mathrm{C} . \pm 0.5^{\circ} \mathrm{C}$.

To each liter of plasma, $92 \mathrm{ml}$. of cold 95 per cent ethanol were added slowly by siphon at a rate of $50 \mathrm{ml}$. per minute. The temperature was maintained at $0^{\circ} \mathrm{C} . \pm$ $0.5^{\circ} \mathrm{C}$. Adjustment of the $\mathrm{pH}$ to $7.2 \pm 0.2$ with $0.1 \mathrm{M}$ bicarbonate was necessary as the $\mathrm{pH}$ of the starting plasma was usually around 6.8. The precipitated Fraction I was removed by centrifugation in a small Sharples centrifuge at $0^{\circ} \mathrm{C} . \pm 0.5^{\circ} \mathrm{C}$, at a feed rate of $50 \mathrm{ml}$. per minute.

\section{Separation of Fraction $I I+I I I$}

Fraction II + III was separated by 25 per cent ethanol, $\mathrm{pH} 6.8 \pm 0.05, \mathrm{r} / 2=0.12$ and temperature $-5^{\circ} \mathrm{C}$.

To each liter of the supernatant fluid remaining following removal of Fraction I, $234 \mathrm{ml}$. of cold 95 per cent ethanol containing a predetermined amount of $\mathrm{pH}$ 4 acetate buffer ${ }^{2}$ was added by siphon at a rate of $50 \mathrm{ml}$. per minute. The temperature was lowered to $-5^{\circ} \mathrm{C}$. during the addition of the reagent. The precipitated Fraction II + III was removed in the Sharples centrifuge at $-5^{\circ} \mathrm{C}$. at a feed rate of $30 \mathrm{ml}$. per minute.

The supernatant fluid following removal of Fraction II + III was clarified by filtration at $-5^{\circ} \mathrm{C}$. through

2 This buffer has a mole ratio of sodium acetate-acetic acid of 0.2 and is conveniently made up by taking: 200 ml. of 4 molar sodium acetate; $400 \mathrm{ml}$. of 10 molar acetic acid and water to make 1 liter. When diluted with water eighty times, it should have a $\mathrm{pH}$ of $4.00 \pm 0.02$ when measured in a glass electrode at $25^{\circ} \mathrm{C}$. 
TABLE I

The electrophoretic distribution of the proteins of the supernatant fluid following drying and re-constitution in pH 8.6 veronal citrate buffer, $\Gamma / 2=0.1$

\begin{tabular}{|c|c|c|c|c|c|c|c|}
\hline \multirow[b]{2}{*}{$\begin{array}{l}\text { Prep. } \\
\text { No. }\end{array}$} & \multirow{2}{*}{$\begin{array}{l}\text { Yield } \\
\text { (approx. } \\
\text { dry wt. } \\
\text { per liter } \\
\text { of plasma) } \\
\text { grams }\end{array}$} & \multirow{2}{*}{$\begin{array}{l}\text { Protein } \\
\text { content } \\
\text { of dry } \\
\text { weight } \\
\text { per cent }\end{array}$} & \multicolumn{5}{|c|}{ Electrophoretic distribution } \\
\hline & & & $\underset{\text { per cent }}{\text { Albumin }}$ & $\begin{array}{c}\alpha \text {-globulin } \\
\text { per cent }\end{array}$ & $\underset{\text { per cent }}{\beta \text {-globulin }}$ & $\begin{array}{l}\text { Fibrinogen } \\
\text { per cent }\end{array}$ & $\underset{\text { per cent }}{\gamma \text {-globulin }}$ \\
\hline 1 & 59 & 60.4 & 80.3 & 14.1 & 5.6 & 0 & 0 \\
\hline 2 & 56 & 65.2 & 82.7 & 11.7 & 5.6 & 0 & 0 \\
\hline 3 & 57 & 62.8 & 81.7 & 12.6 & 5.7 & 0 & 0 \\
\hline
\end{tabular}

Hormann D-8 filter pads with the aid of Hyflo Super Cel. ${ }^{3}$ The fluid so clarified was then dried from the frozen state and stored at $-18^{\circ} \mathrm{C}$. until used.

\section{Electrophoretic distribution of the powder obtained from drying the supernatant fluid}

The protein distribution of three different preparations made by the procedure above has been determined using the Klett Electrophoresis apparatus. The material for the electrophoresis determination was dissolved to a concentration of 1 to 2 per cent with veronal citrate buffer of 0.1 ionic strength and $\mathrm{pH}$ 8.6. Table I shows the protein distribution for each preparation. Preparation 1 represents a mixture of the powder obtained from six, four-liter plasma pools. Preparations 2 and 3 represent the powders obtained from 8.8 and 8.1-liter plasma pools, respectively.

The table shows that the yield of the dry powder from the supernatant fluid in each preparation was between 56 to 59 grams per liter of plasma. This weight was not adjusted for moisture content which is usually between 5 to 10 per cent in our method of drying from the frozen state. The protein content of the powder based on the biuret determination (4) was between 60 and 65 per cent. The protein distribution of the powder was 80 to 83 per cent albumin, 11 to 14 per cent alpha globulin, and 5.6 to 5.7 per cent beta globulin. Neither fibrinogen nor gamma globulin was contained in this material.

The effect of heating for 10 hours at $60^{\circ} \mathrm{C}$. on the optical density of the plasma protein solution

The powder obtained from drying the supernatant fluid following the removal of Fractions I

${ }^{3}$ Hyflo Super Cel was suspended in the supernatant fluid to approximately 0.25 per cent. The filter pads were precoated with Super Cel also. and II + III was reconstituted to a five per cent solution with cold distilled water. The $\mathrm{pH}$ of the solution was adjusted to $6.8 \pm 0.05$ when necessary. The protein concentration was 3.3 per cent as determined by the biuret method (4).

The reconstituted material was sterilized by filtration through Hormann D-3, D-8 and D-10 filter pads, placed into sterile Coleman, Jr. Spectrophotometer tubes, and capped with sterile rubber stoppers. Some of the tubes were heated for 10 hours at $60^{\circ} \mathrm{C}$., while others not heated were used as control tubes. Optical density readings of both the heated and control tubes were made at $550 \mathrm{~m} \mu$ in the Coleman Jr. Spectrophotometer. Table II shows that heating for 10 hours at $60^{\circ} \mathrm{C}$. changed the optical density very little.

The ultracentrifugal and electrophoretic analyses of the unheated solution and of the solution heated for 10 hours at $60^{\circ} \mathrm{C}$.

Heated and unheated samples of Preparations 1, 2 , and 3 were studied in the Spinco Ultracentrifuge Model E. One $\mathrm{ml}$. of each preparation was diluted with $2 \mathrm{ml}$. of $0.15 \mathrm{M} \mathrm{NaCl}$ making an average protein concentration of 1.1 per cent. For each preparation the heated and unheated samples were run at the same time using both cells of the rotor. Each sample was run at full

TABLE II

The effect of heating for 10 hours at $60^{\circ} \mathrm{C}$. at $\mathrm{pH} 6.8$ on the optical density of the plasma protein solution

\begin{tabular}{cccc}
\hline \hline $\begin{array}{c}\text { Prepa- } \\
\text { ration } \\
\text { number }\end{array}$ & $\begin{array}{c}\text { Heat } \\
\text { treatment }\end{array}$ & $\begin{array}{c}\text { Number } \\
\text { tubes } \\
\text { read }\end{array}$ & $\begin{array}{c}\text { Average } \\
\text { optical } \\
\text { density }\end{array}$ \\
\hline 1 & Control & 25 & 0.203 \\
& 10 hours at $60^{\circ} \mathrm{C}$. & 25 & 0.209 \\
2 & Control & 20 & 0.174 \\
3 & 10 hours at $60^{\circ} \mathrm{C}$. & 50 & 0.190 \\
& Control & 20 & 0.192 \\
& 10 hours at $60^{\circ} \mathrm{C}$. & 49 & 0.200
\end{tabular}


speed of 59,700 RPM for 100 minutes and pictures were taken at $5,10,15,20,30,40$, and 100 minutes after the rotor had reached full speed. Five minutes after the rotor had reached full speed a fast moving component was observed in the heated sample of the three preparations (arrow, upper diagram, Figure 1A). Very little of this component was seen in the unheated sample (lower diagram, Figure 1A). Five minutes later this component was hardly discernible (arrow, upper diagram, Figure 1B). Throughout the remainder of the run no components other than the main component in both the unheated and heated samples were seen in the ultracentrifuge pattern.

To ascertain to what extent the main component was decreased due to heating for 10 hours at $60^{\circ} \mathrm{C}$., the area of the main peak of each of the heated and unheated samples was determined from the picture taken 100 minutes after full speed had been attained (Figure 1C). The areas of the main peaks of the heated samples compared with those of the unheated samples in Preparations 1, 2 , and 3 were approximately $86.2,96.0$, and 83.4 per cent, respectively. This indicates that heating causes a reduction in the amount of the main component. Whether the reduction in the main component is accounted for in the fast component has not been determined. The uncorrected sedimentation constant of the main peaks in each of the heated and unheated samples was nearly the same in all preparations, approximately $4 \times 10^{-13}$.

The electrophoretic results obtained on the heated solution of Preparations 1, 2, and 3 showed the protein distribution to be very nearly the same as that in the starting material (Table I). Albumin was approximately 80 per cent, alpha globulin 16 per cent, and beta globulin 4 per cent.

\section{DISCUSSION}

By the use of the cold ethanol method $(3,5)$, Pennell (6) has fractionated plasma to which either T6 phage virus or mouse SK polio virus had been added. He showed that for the most part both viruses were removed in Fractions I and II + III. The supernatant fluid following removal of Fraction II + III contained only a small percentage of the starting concentration of either virus. Murray (7) reported that albumin prepared by the cold ethanol method from a human plasma pool infected with homologous serum hepatitis was not infective in 10 volunteers when it had been heated for 10 hours at $60^{\circ} \mathrm{C}$. When $100 \mathrm{ml}$. of 25 per cent albumin not heated for 10 hours at $60^{\circ} \mathrm{C}$. were given to each of five volunteers, one case of hepatitis developed. Murray and Ratner (8) have demonstrated further that gamma globulin prepared by the cold ethanol method from human plasma infected with homologous serum hepatitis does not produce hepatitis in humans.

The work of Pennell and Murray suggests that both the cold ethanol fractionation process and the heating for 10 hours at $60^{\circ} \mathrm{C}$. are responsible for the albumin solution being free of virus. The

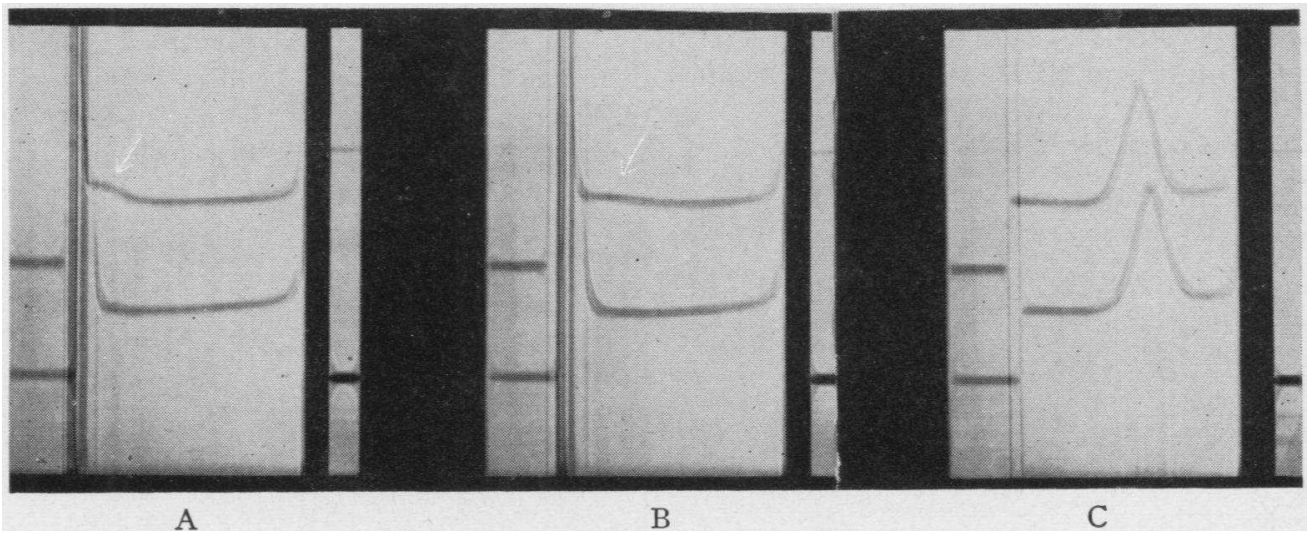

Fig. 1. The Ultracentrifugal Sedimentation Diagrams of the Plasma Protein Solution, Preparation 3

The upper diagrams represent the heated solution, the lower the unheated solution. Picture A was taken 5 minutes after reaching full speed (59,700 RPM); B, 10 minutes after full speed; and C, 100 minutes after full speed. 
method described in this communication makes use of the cold ethanol process to remove the more unstable proteins thus permitting heating for 10 hours at $60^{\circ} \mathrm{C}$. A study of this process on plasma infected with homologous serum hepatitis is indicated. If proven successful in human volunteers, the plasma protein solution resulting could be prepared on a large scale more economically than can albumin with equipment that already exists in the industrial laboratories.

Preliminary studies suggest that acetyl-dl-tryptophanate is a stabilizing agent for the plasma protein solution. The present method is being studied on a pilot plant scale by the Biologic Laboratories, Massachusetts Department of Public Health, Boston. Large volumes of the solution containing acetyl-dl-tryptophanate are being heated for 10 hours at $60^{\circ} \mathrm{C}$.

\section{SUMMARY}

1. A method for the preparation of a stable human plasma protein solution involving the removal of the more heat labile components from plasma with ethanol-water mixtures has been described.

2. The solution contains nearly all the albumin and some of the small molecular weight globulins that are normally contained in plasma.

3. Very little, if any change is observed in the optical density and electrophoretic distribution of the solution following heating for 10 hours at $60^{\circ} \mathrm{C}$.

4. Ultracentrifugal analyses show the formation of a fast moving component in the solution due to the 10 hours' heating at $60^{\circ} \mathrm{C}$.

\section{ACKNOWLEDGMENT}

The authors wish to express their gratitude to $\mathrm{Mr}$. Wayne Parker, Mr. Hugo Zee, and Mr. Donald Warken- ton for their assistance in the preparation of the solutions and the stability analyses. They also extend their thanks to Miss Helen Samaras, Pitman Moore Company, Zionsville, Indiana, for the electrophoresis work.

\section{REFERENCES}

1. Gellis, S. S., Neefe, J. R., Stokes, J., Jr., Strong, L. E., Janeway, C. A., and Scatchard, G., Chemical, clinical and immunological studies on the products of human plasma fractionation. XXXVI. Inactivation of the virus of homologous serum hepatitis in solutions of normal human serum albumin by means of heat. J. Clin. Invest., 1948, 27, 239.

2. Murray, R., and Diefenbach, W. C. L., Effect of heat on the agent of homologous serum hepatitis. Proc. Soc. Exper. Biol. \& Med., 1953, 84, 230.

3. Cohn, E. J., Strong, L. E., Hughes, W. L., Jr., Mulford, D. J., Ashworth, J. N., Melin, M., and Taylor, H. L., Preparation and properties of serum and plasma proteins. IV. A system for the separation into fractions of the protein and lipoprotein components of biological tissues and fluids. $\mathrm{J}$. Am. Chem. Soc., 1946, 68, 459.

4. Gornall, A. G., Bardawill, C. J., and David, M. M., Determination of serum proteins by means of the biuret reaction. J. Biol. Chem., 1949, 177, 751.

5. Oncley, J. L., Melin, M., Richert, D. A., Cameron, J. W., and Gross, P. M., Jr., The separation of the antibodies, isoagglutinins, prothrombin, plasminogen and $\beta$-lipoprotein in subfractions of human plasma. J. Am. Chem. Soc., 1949, 71, 541.

6. Pennell, R. B., Paper at a meeting called to consider the New and Modified Procedures for the Preparation of Stable Proteins from Human Plasma at the Harvard Medical School, April 24, 1953, (unpublished).

7. Murray, R., Conference on Implications of New Knowledge about Proteins, Protein Enzymes and Cells. Protein Foundation, Inc., Cambridge, Massachusetts, January 14, 1952, page 82 .

8. Murray, R., and Ratner, F., Safety of immune serum globulin with respect to homologous serum hepatitis. Proc. Soc. Exper. Biol. \& Med., 1953, 83, 554. 